\title{
Une glace sans tain: the hom(m)eostasis of misogynistic desire
}

\section{Claire Potter}

\begin{abstract}
Une glace sans tain: the hom(m)eostasis of misogynistic desire est un essai critico-fictif qui explore, par le trope de l'homéostasie, comment la mysogynie - comprise comme étant coïncidente au désir - peut être vue non comme la perte de contrôle d'un être, mais plutôt comme le maintien ou l'organisation du contrôle. L'essai postule que l'image de la mère est le sujet principal envers lequel le sujet masculin ou féminin (le spectateur) projette et ancre le désir ambivalent, mais de l'autre côté de la glace sans tain: derrière un double miroir.
\end{abstract}




\section{Une glace sans}

\section{tain: the hom(m)eostasis of misogynistic desire or}

- Acheron (Woe)

- Cocytus (Wailing)

- Lethe (Forgetfulness)

- Phlegeton (Fiery)

- Styx (Abhorrence)

(The five rivers flowing through Hades)

$$
\text { I. }-(\text { Woe })
$$

One year, a century and a half ago, spring might have been late in Paris had Karl Marx and Friedrich Engels not been drawn together in the disillusioned city on the brink of revolution. Winter that year was, on the other hand, very cold: the research of French biologist Dr. Pouchet's influential VIII Loi Fondatmentale (1844) analogised the sexual/menstrual activity of women with les divers êtres de la série zoologique; Dr. Achilles Chereau's less ambiguous thesis followed: Propter solum ovarium mulier est id quod est (It is because of her womb a woman is what she is, 1844). However, these ideas of inveigling simplicity were not French:

- Lancet 1842-43: A post-mortem examination carried out by a Dr. Chowne on Mrs. G, aged 37, a married woman who had enjoyed general good health, revealed that the woman's uterus and its appendages were in that conglomerated state which is usually observed in women who have led an irregular life, and which was, probably, in them, dependant upon early and excessive excitement. This adhesion of the ovaries... [found] in prostitutes, had been noticed in France.

Rut: [L. rutilus reddish]

1. The periodic sexual excitement or activity of male deer, antelope, goats, etc. The Shorter Oxford English Dictionary (SOED).
- Lancet 1843: Considered with respect to her generative function, woman holds a place intermediate between rutting animals... and those animals in which a coitus only is required to produce impregnation at any time of the year...her power of reproduction being infinitely more active 
at her menstrual periods, to which the rutting time in brutes bears a strict physiological resemblance.

And this is in fact what we find happening: not only was the womb the constituent organ of woman, but it was an impassable matrix within which the female psyche lay

imbedded, carved, ensnared - woefully within the broderies of (her brutish) flesh

within the broderies of prime matter

And this is in fact what we find happening; for the natural substance of the menstrual - perhaps resembling the particles of lavender face powder my grandmother used to wear -

fuid is to be classed as 'prime matter'

$m ? t ? r / m a t ? r$

maternelle / material (pr_t_hyl_).

matière / matter Generation mother / metre of Animals, Aristotle.

mutter / madre mamma / mamilla The substance of language? The matrix of discourse? A matrix of appropriation?

Speculum,

Luce

Irigaray.

Uxoricide? Who says there isn't a word to capture - at one and the same time - the killing and loving of one's wife?

for the over-throw of matriarchal lineage (mother right), Engels observed, was the world-historic defeat of the female sex, such that the child, male or female, and the father for that matter, could escape from any unnatural attachment regression - to pre-Oedipal matter.

Extending Marx's thesis of sexual exploitation: "The first division of labour is that between a man and a woman for The German Ideology, 1846 Marx. child breeding", Engel's analogised the first class oppression with that of the female sex by the male. For Engels, the domestic and matrimonial sphere - the cellular form of civilised society - afforded evidence that every advance [of mankind] could be also seen as likewise a relative regression, in which the well-being and development of one group was attained by the misery and repression of the other.

Hark!

The Origin of Family, Private Property, and the State 1884 , Friedrich Engels.

A rutting womb that wanders -

Render it interpretable

re(as)semble it resort to the speculum to touch the untouchable 
to keep himself from total deliquescence

to pin it/her down: a frozen chrysalis

so that the eye can enter

so woman becomes the "object" to envisage

rolled up in metaphors

frozen in show-cases

the representing-representative of negativity (of death)

"Volume without

specula(ris)ed

contours", Luce

having nothing to say

Irigaray.

i. A woman sits blankly on a chair. She has nothing to say even though below her, on his knees, he is begging her to speak of her desire ... (for him)...

It is true, Irigaray writes, that women do not tell all, especially since woman is notall, ce rien du tout, what more could there be to say?

There is enchantment in these alchemies, there is poetry in making preserves; the housewife has... enclosed life in jars.

Le Deuxième sexe,

Simone de Beauvoir.
"And there you have it, Gentlemen, that is why your daughters are dumb", their connections to their mothers have been renounced or in the least re-announced; palatised under the calming yoke of phallic desire so based in disavowed erotics (love), that housewives might have found it worth jarring had it been more easily quantifiable

and yet how to measure the minutiae of stases, the stoppage of fluid, the current of blood? The weight of a heart beat?

For a drop in temperature is just as mercurial

as the raising of blood to boiling point

as the click of a key in the front door

as the creaking of wooden chairs

Tropismes V,

as the shrill notes of the locusts

Nathalie

as the piling of china plates

Sarraute.

as a shadow in flight

as violence splitting silence: a burst ink balloon

but now in the corner of the room, curled against the light, he sleeps. His cooling body rests - an induced, narcissistic hom(m)eostasis, a desperate, circular evasion

Homeostasis: [f. homoeo + Gk. stasis standing still, stationariness] 1 . The maintenance of relatively constant conditions in the body (e.g. as regards blood temperature) by physiological processes that act to counter any departure from the normal. SOED.

\section{Rest/Motion}

a woman watches (over) him: she is unable to sleep, rather she is forbidden sleep. She stands in the middle of the room, drawing the air in an anti-clockwise spiral around her. Gravity pulls on her fingertips; the pupils of her eyes retract in slow motion. Can we find in her stature the trace of his 
misogyny? Shall we name her sleeplessness - in the face of his sleepfulness misogyny?

misogyny: Gk. misos "hatred" (from misein "to hate) + gyne "woman".

How to measure this woman standing

this man sleeping

their sexual distance

their sorrow

the extent of his detachment

the depth of her woe?

How to conceive (of) a girl?

Speculum, Luce Irigaray

ii. One autumn afternoon in 1893 a father led his daughter - une petite hystérie to the office of Dr. Sigmund Freud. Historically, for eighteen years, Dora (as she would be named) had been suffering from, amongst other things:

Bed Wetting, Fainting, Aphonia, Appendicitis, Aphasia, Dyspnoea, Depression, Facial Neuralgia, Asthma, Coughing, Migraine, Suicidal Tendencies

Gastric Pains, Paralysis, Amnesia, Catarrh (Leucorrhoea)

After three months of treatment with Freud, Dora broke off her analysis and with the heartiest wishes for the New Year ... came no more. Although this premature rupture in Dora's treatment was derivative, amongst other things, of Freud's fledgling experience in the dynamics of counter-transference, the first psychoanalytic journeys into the human unconscious had been made. Dora's symptoms were traced back to her family life, to her childhood desires; her gain from illness was underscored and her repressed sexual desire for her father, manifest in her conscious admiration for the adorable white body of her father's mistress, Frau. K., was noted by Freud.

Unexamined however remained Dora's feelings towards her uncultivated and foolish mother, a woman suffering from housewife psychosis - she cleaned all day referred to by Freud and reputably by Dora only ever in the third person and through the lens of Dora's most intense dislike for the woman - a dislike read by Freud as the poetical rendering of the Oedipal complex.

And yet, the Dora "case", despite its initial smoothness, possessed The Dora case had a riddle, a lock that did not give way so easily to Freud's collection of picks: the conundrum of female desire - the riddle that Freud later admitted he ought to have earlier attacked. Nonetheless, Freud's version(s) of female desire continued along more or less the same vein until 1923 when a footnote was added to the Dora "opened smoothly to my collection of picklocks".

Letters to Fleiss, Freud. 
case which revealed what Freud had finally come to recognise as the strongest unconscious current in Dora's mental life: her homosexual love for her father's mistress: Frau. K.

It is also necessary, if
we are not to be
accomplices in the
murder of the mother,
for us to assert that
there is a genealogy
of women. Le corps-
$\dot{a}$-corps avec la mère,
Luce Irigaray.

Bravo and still nothing on Dora's mother. Nothing on the possibility of Dora's prolonged struggle with the formulaic Oedipal complex, on Dora's incommensurable intellectual and psychical effort to shift her desire to the opposite sex, on Dora's significant mimicking of her mother's catarrh, her female cousin's gastric pains, very little on her two hour rapturous gazing at Raffæl's Sistine Madonna, on Dora's hiding of a letter from Freud - her grandmother's letter - a forbidden genealogy (of love?) held guiltily, guilefully, in her hand, behind her back - the letter arrived but was never read - and Freud was led to dismiss it as a matter of complete indifference and of no relation to the treatment. I believe that Dora only wanted to play 'secrets' with me...

"I did not understand and was obliged to ask her to repeat [her secret] several times...The sound of Nambikwara speech tends to be muted...the women like to emphasise this characteristic by distorting certain words; by articulating indistinctly, they produce a kind of mumbling reminiscent of children's speech..."

Tristes Tropiques, Lévi-Strauss.

\section{II. - (Wailing)}

A three year old boy is left in the desert to avert the prophecy of the oracle that he will wed his mother and kill his father. Although the child's ankles are pierced by its parents so it cannot follow them, it does not perish. Conversely, the child is by chance found by a shepherd and brought to the childless King and Queen of Corinth who take the infant as their own and name him Oedipus, or "swollen foot".

Many years later, when the virulent prophecy of the oracle again resurfaces, the young Oedipus flees his parents - whom he thinks to be his own - and makes his way unsuspectingly towards Thebes, his place of birth. On the way, the first part of the prophecy is fulfilled: Oedipus murders a stranger who, unbeknownst to him, is his father, and the plague thus descends on Thebes as predicted.

Still drawn towards the Thebes - and we are never told why - at the city gates Oedipus encounters the Sphinx, a half woman, snake, bird, lion, who will only permit him entry if he can correctly answer her riddle: What in the morning walks on four legs, at noon walks on two legs and by night walks on three legs? 
Oedipus' cunning yet fateful answer - "Man" - conquers the stronghold that the Sphinx (described by some as a "terrible monster") has on Thebes, and she throws herself from the city walls and perishes

perhaps in the high sun of noon,

perhaps at the foot of the gate

certainly alone.

And I wonder at the violent death of this woman-snake-birdlion monster and wonder if there might have been a different answer to her riddle, one indeed that did not prove the accuraMater Dolorosa: the virgin who weeps at the foot of the cross for her crucified son. cy of the oracle's prediction, for in answering "Man" Oedipus accentuates his being that man who, after killing his father and marrying his mother, blinds himself and must walk for the rest of his days with the aid of a cane - an artifice - that is, on three legs.

If for a moment we imagine that there might have been a different answer - one that defied the oracle's prophecy - might we not also imagine that the Sphinx was offering Oedipus the chance of a different future, that she was not menacing but facilitating this different future? Might not the riddle have been but the semblance of a riddle, that is, a seemingly insolvable question whose very insolvability marked the possibility of an otherwise? Was not the riddle offered to Oedipus a riddle qua riddle - the opportunity not simply to get it right but to shun a destiny not written by Oedipus but by someone else, a destiny nonetheless purportedly symbolic of Oedipus' own desires?

Let us imagine the city gates to be a threshold: for in the past, behind the Sphinx lay the murdered body of the stranger/father and in the future beyond the Sphinx lay the not-yet dead body of the mother/wife. In his answer - "Man" - does not Oedipus' pain-to-remember rather than his triumph-at-forgetting bade in the same way, a return to his mother but a return to her as " wife and not as woman? Can a distance be permitted between the two?

Elle est plus mère qu'épouse.

In other words, could Oedipus have lived, just for one moment, without his vulgar attachment to the present? to his pre-sent destiny, where woman is only womansnake-bird-lion or woman-mother?

How could Oedipus' answer have been otherwise? For all things considered, we surely cannot confuse a child on all fours with a man unless we... we cannot say that this child is already a man, or can we? Who is this we that speaks?
But if mothers could be women, there would be a whole mode of desiring speech between mother and daughter, son and mother...

"The Critique of

Patriarchy" Luce Irigaray.

\section{J.-P. Sartre.}

The belief, for example, [is] that it is necessary to become a woman, whereas a man is a man from the outset.

"Questions", This Sex Which Is Not One, Luce Irigaray. 
Let me imagine Oedipus replying differently, if I can. Let me imagine something I could call a "temporal escape", where the woefulness of Oedipus' historical curse is permitted a tiny aperture or a present absence in his thoughts when he found himself at the painful crossroad represented by the Sphinx (a closing) and the city gates (an opening). Let me imagine Oedipus

Pain has turned remaining at this threshold, or at least within the impossithe threshold to stone. ble question that was posed to him which seemed, but only Georg Trakl. at a first glance, to be an impasse, an impassability... a stone...

So instead of the narcissistic flight into himself - Man - Oedipus might have remained before the Sphinx, and rolling amongst the words of her question - What in the morning walks on four legs, at noon walks on two legs and by night walks on three legs? - without wanting to swallow or digest them, he might have answered her otherwise...

Wallow: L. volvere to roll.

and what if this remaining, this rolling (a wallowing) brought Oedipus not back to the point of hom(m)eostatic deferral: "Man" (an answer which kept all levels of agitation in check,

Oedipus, André Gide. no matter what the question), but instead returned him to the repressed presence of the earth upon which he crawled, walked Notre mère la as a man and would lean upon as an old man, such that Oediterre. pus' answer might have been: man born of a woman. A man born differ-ently, that is to say, of a woman.

Might this answer have averted the Sphinx's death? Oedipus' blindness? Jocasta's noose? Antigone's immurement? since it would have acknowledged, at one and the same time, that the passage of child to man is not assured, not static, not reductively hom(m)eostatic. In this way, and in the face of the oracle's prophecy, Oedipus would have indeed neither forsaken his past, nor his mother, nor his birthplace; nor would he have been "blind" to recognising his mother, nor would he have physically and psychically sought her palimpsestic replacement (mother qua wife), an erasure which in fact riveted him all the more tightly to her ... bringing on a repression that cost him more than his eyesight, for in losing his sight Oedipus was able to see more clearly - beyond the dead, impeached body of an asymbolic mother - Oedipus saw the materiality of his mother's dead body, his (s)kin hanging from the ceiling before him - a sight that he in fact cannot bear to see the shroud of his supposed castration, his face mirrored in the silvery lake

and so in fright, in shame, in horror Oedipus takes the brooch from his mother's dead body and gouges out his eyes, piercing his sight - like his ankles - throwing himself again to the earth like a child, again he can hide nowhere, again entombed by darkness 
certainly, the forgetting of his mother brings about Oedipus's fall and permits he thus marry her - for is not the apogee of his horror most hideously realised when he discovers that despite his most deliberate efforts, Jocasta, his mother, is indeed his bride? For in fleeing his mother - read by Sophocles as Oedipus'

It often happens that neurotic men declare that they feel something uncanny about the female genital organs. This unheimlich place...is the entrance to the former Heim [home] of all human beings... "The Uncanny" Freud S.E.

Vol. XVII. (1917-1919) most loathsome, yet unrivalled desire - Oedipus is brought even more incestuously, even more unswervingly, even more uncannily, right back to the place (Heim) of his original abode. Might an earlier recognition of the mother, of Oedipus' mother, have been what the Sphinx was trying to bring Oedipus to articulate?

Enter here perhaps some (re)marks on misogyny:

1. The flight from the mother that man enacts,

at time forcefully

at times violently

at times sheepishly

is marked with the father's blessing.

However a blessing - une blessure - accepted at what price? Fort-da.

At the price of man being reeled back towards the (m)other with the force of an unbound umbilical cord never properly cut, but replaced - quashed as Irigaray might say - with the impossible weight of phallus, demanding that the show must go on? The phallus: transcendental orderer of the sensible world, necessarily building itself on the totemic figure not of the murdered father but of the dancing, primordial mother desired by all her sons?

$$
\text { Hark; a taboo is in the air... }
$$

Guilt more ancient than the immolated father? Let us for a moment try...

no nothing

move on

say something else.

For having slain his mother, Orestes, the son of Clytemnestra, is pursued by the Furies - a troop of enraged women who haunt him wherever he goes - who are sent by Clytemnestra lest her son forget his crime. Orestes is driven almost mad by the presence of the relentless women, however the matricidal son must be saved from madness to establish the patriarchal order, and it will be Electra, Orestes sister, who becomes the
Le corps-àcorps avec la mère,

Luce Irigaray.

\author{
Orestia, \\ Aeschylus. \\ Le corps-à- \\ corps avec la \\ mère, Iuce \\ Irigaray.
}


totemic figure, and who is in turn is immolated by her children. The murder of the mother results in the non-punishment of the son, and the burial of madness in women - and the burial of woman in madness... For is not the killing of the mother in fact the most disavowed coupling with her? Was the unsatisfied Phèdre not written by Racine as pleading for Hippolyte's sword?

... once the man- Irigaray writes: The Furies cry vengeance. They are women in god-father kills revolt, rising up like revolutionary hysterics against the patrithe mother so as archal power in the process of being established, they are to take power, he genies out of the bottle, summoned by the dead mother just is assailed by until

ghosts and

anxieties. He will their presence is questioned by Athena, who must judge the always feel a matricidal crime of Orestes and who is herself perturbed by the panic of she who Furies presence. She asks:

is substitute for

who he has killed. ATHENA

"Women- Who are ye?

mothers, the

silent substra-

LEADER OF THE FURIES

tum",

$O$ child of Zeus, one word shall tell thee all. Luce Irigaray. We are the children of eternal Night, And Furies in the underworld are called

\section{ATHENA}

Say, do ye bay this man to such a flight?

\section{LEADER OF THE FURIES}

Yea, for of choice he did his mother slay.

Question: Is not misogynic desire the taming of one's own Furies, the ones who haunt my psyche for my matricidal tendencies? For better to hate an object than to love it, lest it get the wrong impression? Furies who haunt me for the inversion of my desire - the switching my consumption of her into her consumption of me? How else to rationalize the fact that there was never any reason to fear castration (by her): the umbilical cord, as Irigaray notes, had been already cut! What else was there to cut off? Cut out?

For the erasure of the ground - of la terre, of la ma-terre if I may say so - will ensure all future unsteadiness of the feet. Will ensure the need of a walking cane, a third leg, a way out of the cave, a hom(m)eostatic deferral

Love is banishment.

First Love,

Samuel Beckett. therefore the boy's turning from his mother - a turning reinforced (defensively?) by the father - always begins with a wail: how else to turn from the place that was our first love without naming it/her banishment? She expulsed me. 
And although the child might cry at the beginning, upon being shown that the mother in fact doesn't even have what it takes, he will none too reluctantly take up his place with the one who does: du-pered into believing that his desire for his mother was all wrong, he will position his ladder, inadvertently, yet squarely, right on top of her dreams...

...Tread softly

because you tread

on my dreams.

Yeats.

\section{limited/unlimited \\ presence/absence \\ oddleven \\ possession/lack \\ male/female \\ fear/envy \\ $\mathrm{good} / \mathrm{bad}$}

and so it goes, the pèreversion of the child's world builds itself upon not a straw-man but a paper-maché mother. But this disavowal is ambiguous, for the figure of the father at the same time forbids as well as takes the mother's body for himself, which to the child must surely make no sense at all ...Let me see: four times five is twelve, and four times six is thirteen, and four times seven is - oh dear! I shall never get to twenty at the rate! ... unless of course the logic has already been treated to the play of the double mirror - la glace sans tains - behind which the child is permitted the (spectral) enjoyment of the mother's body, but from the "other side" of the looking glass, where the mother cannot see the child, but where the child can see, enjoy, examine, spectralise, specularise her. A speculum in his hand, a globe, a bobbin, a reel, a purview...

\section{III. - (Forgetting)}

But the child remains fearful of the mother - what if she should discover my betrayal, my desire, my deliberate forgetting of her, a forgetting transmuted into the specular(is)ation of her body?

This fear, manifest as malaise towards an all-encouraging father, is retroactively projected onto the archaic relationship with the mother such that the mother become [s] a devouring monster ... a devouring mouth, a cloaca or anal and urethral outfall, a phallic threat, at best reproductive... There are no

Le corps-àcorps avec la mère,

Luce Irigaray. words to talk about her,

except filthy, mutilating words to snuff her out, words steeped in misogynistic desire giving way to a language of utterance, of muttering, of mutterance: a hatred ambivalent, desiring, debasing and shameful of its secret underside: betrayal. 
mother: 1. Dregs, scum, orig. that of oil, later that rising to the surface of fermenting liquids. 2 . In full mother of vinegar. A ropy mucilaginous substance produced on the surface of alcoholic liquids during acetogenic fermentation...

Shorter Oxford English Dictionary

and the most remarkable characteristic of melancholia is its tendency to change into mania - a state which is the opposite of its symptoms, wrote Freud. And so thanks to games with convex mirrors, the fires started with hate are only rarely permitted the cure of love

If the love for the performative amnesia - a deliberate "as if" I never knew, an object - a love which enacted forgetting - forms the only way out of the love-hate cannot be given up - bind, unless misogynistic desire (I love her, I love her not) takes refuge in nar- is not completely given over to...

cissistic identifica-

tion, then hate comes Misogyny:

into operation on this a word

substitutive object, a pendulum

abusing it, debasing to be used with extreme wariness - as though time were it, making it suffer bountiful and we had pause to think - is the instance of and deriving ...satis- ambivalent, melancholic love worn as hatred for the mothfaction from its suf- er. Displaced onto Woman in all her vulgarised generalness, fering. "Mourning misogynistic desire ratifies its paradoxical ambivalence by and Melancholi", erecting a steadfast, formulaic, presence...

Freud SE. XIV, 19141916.

but they say it's only a word they say words mean nothing words aren't but words?

Les Guérillères, I refuse to henceforward speak this language, I refuse to Monique Wittig. $\quad$ mumble after them the words lack of penis lack of money lack of insignia lack of name...

The enacted forgetting of the mother, of one's desire for the mother, (re)instils itself as the all-too painful rem(a)inder of that which cannot be (entirely) erased. Without recourse to criticise of the father, the receptacle of woman becomes the

Speculum,

Luce Irigaray. body that is lacking, the body that gathers surplus waste, l'incontournable volume, the fetishised merchandise... 
IV. - (Fiery)

Misogyny:

- matricidal dishwater

- free expression

- minuscule scratches on feminine veneer

- a hermetic sponge

- ambivalent desire worn as fiery hatred: a galvanised heart on the sleeve

- a bloodied footprint

- the ability/tendency of a masculine subject to maintain an internal equi

- librium by defensively refracting the malaise of prohibited desires onto

- the (debased) bodies of Women: a narcissistic hom(m)eostasis: the expul

- sion of $i t$

- the tragic displacement of an eroticised hatred (Eros) of the mother onto deathly hatred (Thanatos) of women, a hatred otherwise meant for the illperceived mother's submittal to the father's "no" (non-du-père): an induced hysteria

- the hatred of the self for desiring the other's desire of me, for wanting her presence - for it is women who desire (what they don't have) and not men who don't desire (what they already have)

- the hatred of the self for submitting to the name-of-the-father

thus set in motion is the uneasy yet secure siding with the father that reinforces an enacted hom $(\mathrm{m})$ osexual distance from the mother. The more I debase women, the further I am from being a woman, the further I am from touching upon my desire for my mother's desire, the one whom I loved, the one from whom I was taken...and my hate acquires an erotic character... I enact a self-preservation...Allow me to forget

"Instincts and their Vicissitudes" Freud, SE. XIV 19141916. (her forgetting of me).

Narcissistic hom(m)eostasis - the discharge of energy/the defense against tension predicates itself on forgetting, on controlled, expelled, neutered desire stabilized upon essentialised representations of women which reverberate, senselessly, within a dialectic where master and slave are at once female: the overcoming of the one by the other, the other by the one, the overcoming of dis-order by the re-writing of the pre-order: a woman, a queen, a pawn in one

but why call stases misogynistic? Because while hom(m)eostasis draws its equilibrium, its elixir, from the monolithic hatred of Women, it masks a more unspeakable guilt: the walling up of the mother within the (false) circuitry of the father? We have been told, I was told last week, it is the father who forbids, it is the father's No that said: "No Camille, I do not love you". 
And so poor Camille Claudel fell into madness because Rodin rejected her - or because he was just not that into her - and he said "No" to her love ... and because Camille, a woman needing the affirmation, the navigation of a man's love in her life, was unable to cope with this "No", she sought refuge in psychosis, in other words she fell over the

edge.

Or at least this is what was pèresemé by the gentleman lecturing on la question de l'affect dans la folie au féminine: "Any theory of Camille Claudel à Virginia Woolf...«la folie au the 'Subject"', féminine»...Monsieur, je vous applaudis à dix mains...et le lot Luce Irigaray. «féminin» n'a maintenant rien à dire...

but it is phallis interdiction that remains unanalysed, uninterrupted, uninterrupted until, mutatis mutandis, the father is written as the one immolated by the sons, and the mother is left not in second place, not as second sex but in the place of the "not", of the not-all-there - ce rien $d u$ tout.

Misogynistic desire (may I distill it for a moment?): a masculine subject in male drag, masquerading as $a$ himself so as not

That elsewhere of female pleasure can only be found at the price of crossing back through the mirror that subtends all speculation. "The Power of Discourse", Luce Irigaray. to draw attention to himself, to his desire. Inserting a space between the I (je) and the myself ( $m o i)$, the performing masculine (or feminine) subject, little by little, by cutting a tiny valve into his desire, and by mooring himself/herself to the rigidity not of his, but of the other's sexuality, manages to enact a selfescapade so gallant that the stricture of his borromean desire is successfully and temporarily averted, and the steam from loving too much can momentarily escape, elsewhere

therein to hate the misogynist or piously wash him with tears? "But does it still exist - misogyny that is," a young woman recently asked me, "because I don't think it does, or at least it is not so clear how it does anymore," she added.

\section{V. - (Abhorrence)}

Early dusk and a coffin is lowered into a dark cinnamon oblong edged with mourners. 


\section{Square/Oblong}

I am in the coffin. But I am not dead, or at least I don't think I am. Spadefuls of earth drop onto the lid of the coffin: a tired heartbeat. The small pockets of air become sullied with the odor of dampening wood. I violently awaken: the dream is unsupportable.

Sometimes, when Irigaray writes of the mother (A mother? Whose mother? Mine?) I am repulsed, even frightened by her words; perhaps even more so in translation when my maternal tongue (ma langue) pushes her translated words into something (la lalangue) resembling an adieu (an a-dieu, contre-dieu): a farewell to forgetting, and a farewell to the discourse of the father who says:

With respect to the treatment of local hysteria, I believe that the best thing you can do is to direct your patient's attention from her local sufferings, and if possible, to induce her to forget them... Lancet, 1942-43.

Conversely, Irigaray's words are the mis en relief of the unsaid, her words (Furies in themselves) do not let me forget:

The imaginary and the symbolic of inter-uterine life and of the first bodily encounter with the mother ... where are we to find them? In what darkness, what madness, have they been abandoned? And the relationship with the placenta, the first house to surround us, halo we carry with us everywhere, like some security blanket, how is that represented in our culture?

To some people the idea of being buried alive is the most uncanny thing of all...psychoanalysis has taught us that this terrifying phantasy is only a transformation of another phantasy...intra -uterine existence. "The Un c a n n y" Freud, S.E. Vol. XVII (19171919)

"Any theory of the 'Subject", Luce Irigaray.

But why abhorrence at these words? For the same reason I don't drink milk, for the same reason I used to play soccer, for the same reason a man in the street passes me and spits the word putain at my feet:

...this madness is not ours. We would do better to take back our own madness and return men theirs! Le corps-à-corps avec la mère. Luce Irigaray.
I likewise encrypted her, guiltily, coldly, one day long ago, when I found my love for her unbearable, or was it hers for me? When I believed her silence was a betrayal. When I read her gaze as Medusian - glaring, violent, suffocating. When I hated her for not interrupting my heterosexualising passage to adulthood, gilded by my father. When I liberally answered those who asked: no I wasn't feminist ... I didn't like feminism. So brave I thought myself to have forgotten her

and then came the next banalising stage: misandry. When he was to blame for it all, when I, beautifully, hysterically oscillated from hating her to hating him 
which did not amount to the same thing since she, in the latter case, remained displaced, replaced, doubly

Do women share ... in the horror of their own blood? Is it this induced makes them hate their mother's sex? Irigaray, "'French women', Stop Trying" in This Sex Which Is Not One...

"The Eternal Irony of the Community" Luce Irigaray. repulsion that

at all times. Is not feminism - with an "s", without an "s" guilty of building its armory from the flesh of the mother? Keeping the masculine, the male, always centrifugal, the lead actor, the force around which, into which the mael strom of feminine desire, madness is post-consciously emp tied? Je suis coup-able donc châtrée non?

Fury that should have been remained towards her? For none of that damn sisterliness can arrive before the work is done, amongst women, differentially...

For as long as the figure of the phallicised father, read in all its forms, remains the screen which absorbs, as well as projects and protects feminine rage and then washes it away, the mother (phallic or not), and the relationships between women (similar or not) will continue to be terrined, enclosed into jars, baked into obscurity, fossilized into vapor: reflected

elsewhere

behind the double mirror - la glace sans tain a bloodless shadow

like the parched hands of my grandmother held above her head to drain the colour away...

"Women's Exile", The relationship of women to their mothers and to other Luce Irigaray. women - thus towards themselves - are subject to total narcissistic 'black-out'; these relationships are completely devalued. Indeed, I have never met a woman who does not suffer from the problem of not being able to resolve in harmony, in the present system, her relationship with her mother and with other women...

VI. - (Later)

And so the movements:

\section{Wailing}

Woe

Forgetfulness 
Fiery

Abhorrence

"Any theory of the "Subject"",

have taken place. And the archaic credit accorded to the all- Luce Irigaray. powerful mother was nothing, was but fable after all.

My sister complains to me of our father - such a fucking arsehole, she says one morning.

- So was she, I replied.

- No, it was him.

- Really? You mean you have no problems with her?

- No, none.

Two days later, in a chasm of blue light, she tells me the following dream: $A$ house was burning. An apron had caught fire. I dressed quickly to get away but a woman told me I couldn't leave since it was cleaning day and she needed to be paid.

- It was a fucked dream, I was scared of the woman in it, I knew she wanted to stop me leaving, she wanted to tell me I had to stay, she said through tears.

No such malaise had accompanied her slighting of him - such parlance: male bashing don't we call it? is normal enough, fashionable enough, encouraged in certain circles, vented obtusely, as stupid and as inconsequential as neutral pantyhose - how long we take to look natural

but a word of hatred against her? a spoken trace without an evaporating silvery trail? What does it mean to say $I$ hate her? that a woman has reason to hate a woman? A blind spot ignored by those who wave sexism like a victory flag:

white lace \& satin was never soiled by sexism.

Janice

Mirikitani.

My sister sat flicking a cigarette lighter on and off: the blue flame quivered in the light. She sat tying and untying an assortment of dream-knots so large that she might have hung herself from them had she not been dreaming.

On the one hand she saw her hatred of our mother in terms of an unspeakable betrayal of herself - as woman, against women - and on the other she saw it as an uncomfortable siding with her father, the betrayal of her mother's rightful place. It was a betrayal that she had carried for so long around with her as an uncertain, but paternalised souvenir: the embodiment of her pain, the regulator of her pain, of her love. But a souvenir gar- "Being Two, How Many Eyes

nered at what price? From where? From whom? Have We?" Luce Irigaray.

...to look ...at something constructed makes us belong to a common ground by which our manner of seeing is in part mortgaged by the intention of the person who constructed it: our seeing is partly determined by their scheme, by their hand, or worse by their machine. 
From

which bleak country?

Freud's dark continent?

Irigaray's darker continent?

\section{Light/Dark}

No, it was a souvenir that I saw my father once give to her, in the form of a fairytale that had been passed to him, one winter's evening, by his father's father. The souvenir took the form of a coin; on one side it was gold, on the other side it was green. He told her the golden side of the coin represented prosperity, the prosperity that would be bestowed upon my sister if she gave up her desire for her mother and sought to re-create with him a new fictionalised desire, one that would lead her out from behind the symbiotic, maternal mirror and into the glittering market of knowledge, of (mé) connaissance, of civility, of calming hom(m)eostases - the world my father frequented

... the green side of the coin represented choice - the choice of whether or not to scrub away the green, for our father said it was only oxidisation: if she cleaned it away, a new golden underside would reveal itself, but if she kept it green, it would be without ever knowing what greater wealth lay beyond, elsewhere.

Seduced, she started scouring the coin

like I had done before her.

Then she hid it

like I did

like Dora did

from our mother

in her pockets, behind her back, pressed sweatily into her oxidising palm.

However she did not know back then, as no child of three could have known, the laws of chemistry and nor had she been told them by our father, for it was assumed she would not understand. And so the more the coin was scrubbed and hidden the greener it became for the salt from her skin corroded the coin and tarnished its surface with sweat, colouring its underside a nice verdegris had she decided to leave the pigment and not furiously scrub it away.

The fear instilled into us by our father - lest our mother saw not the coin, but our scrubbing of the coin - meant we had formed such a pact with him that its breaking would result not in his extradition, but ours, since it was we who had accepted the coin

traversed the mirror

sold our respective desires

in the first place,

in exchange

for the feeling of a funeral in my brain

Emily

Dickinson. 
(He assured me that it would always be her in the coffin, but in my dreams it is always $m e$ )

and so from the guilt grown in our bleak hothouse of disavowal, we drew our guile until a certain grey afternoon passed and there was nothing else to clean and my sister and I decided that it would be best if we attempted the speaking of it all, beginning at the end:

that fateful spring day when

we plucked a narcissus and

the earth opened up before us.

\section{Bibliography}

André, Jacques (ed.). Mères et filles. La menace de l'identité. Paris: PUF, 2003. Aristotle. Aristotle: Generation of Animals. Tr.AL. Peck, Cambridge: Harvard University Press, 1963. Barthes, Roland. Le Plaisir du texte. Paris: Seuil, 1973.

Beauvoir, Simone de. Le Deuxième sexe. Paris: Seuil, 1949.

Derrida, Jacques. 'La Double séance' in La Dissémination. Paris: Seuil, 1972a, pp. 201-317. Freud, Sigmund. (1905) 'Fragment of an analysis of a case of hysteria', tr. James Strachey (ed.). Stanard Edition Vol. VII (1901-1905). London: The Hogarth Press, 2001.

- (1917) 'Mourning \& Melancholia' S.E. Vol. XIV (1914-1916). London: The Hogarth Press, 2001.

- (1914)'On the Tendency to Debasement in the Sphere of Love', tr. James Strachey, in The Freud Reader. Ed. Peter Gay, Canada: Penguin, 1989, pp. 394-400.

Hamblet, Wendy C. The Sacred Monstruous: A Reflexion on Violence in Human Communities, USA: Lexington Books, 2004.

Gallagher, K. \& T. Laqueur. The Making of the Modern Baby. Berkeley: University of California Press, 1987.

Irigaray, Luce. Speculum. De l'autre femme. Paris: Les Éditions de Minuit., 1974a. - 'The Rape of the Letter, in To Speak Is Never Neutral. Trans. Gail Schwab, New York: Continuum, 2002.

— 'Mères et filles vues par Luce Irigaray' in Libération, 21 mai 1975.

- 'Women's Exile', tr. Couze Venn in Ideology and Consciousness, 1, pp. 62-76.

- 'Women, the sacred money' in Paragraphs: The Journal of the Modern Critical Theory Group. (Oct. Vol. 8) Trans. Diana Knight \& Margaret Whitford, pp. 6-18.

- Key Writing. Ed. Luce Irigaray. London: Continuum, 2004.

Lauretis, Teresa de. 'The Violence of Rhetoric: Considerations on Representation and Gender' in The Violence of Representation, Nancy Armstrong \& Leonard Tennenhouse (eds.). London: Routledge, 1989.

Sarraute, Nathalie. Tropismes. Paris: Éditions de Minuit, 1957.

— L'Ėre du soupçon. Paris: Éditions de Minuit, 1956. 